\title{
Development of a bioaffinity SPR immunosensor based on functionalized graphene oxide for the detection of pregnancy-associated plasma protein A2 in human plasma
}

This article was published in the following Dove Press journal:

International Journal of Nanomedicine

\author{
Nan-Fu Chiu' \\ Ming-Jung Tai' \\ Hwai-Ping $\mathrm{Wu}^{\prime}$ \\ Ting-Li Lin' \\ Chen-Yu Chen ${ }^{2,3}$
}

'Laboratory of Nano-photonics and Biosensors, Institute of Electro-Optical Engineering, National Taiwan Normal University, Taipei II677, Taiwan;

${ }^{2}$ Department of Obstetrics and Gynecology, Mackay Memorial Hospital, Taipei City 10449, Taiwan; ${ }^{3}$ Department of Medicine, Mackay Medical College, Taipei 25245, Taiwan
Correspondence: Nan-Fu Chiu Laboratory of Nano-photonics and Biosensors, Institute of Electro-Optical Engineering, National Taiwan Normal University, No. 88, Sec. 4, Ting-Chou Road, Taipei I 1677, Taiwan

Tel +886 277346722

Fax +886286631954

Emailnfchiu@ntnu.edu.tw
Background: Graphene-like material such as functionalized carboxyl-graphene oxide (carboxyl-GO) can be intelligently tuned to achieve particular properties for biological and chemical sensing applications.

Methods: In this study, we propose a method to improve interference of non-specific proteins for use in human plasma assays. The highly specific interactions between molecules are an advantage of carboxyl-GO-based surface plasmon resonance (SPR) immunoassays, and this can be applied to spiked plasma samples with pregnancy-associated plasma protein A2 (PAPPA2).

Results: The experiment results showed that carboxyl-GO could be used to modulate the plasmon resonance energy, work function and conductivity properties. In addition, carboxyl groups could be used to enhance the conduction of electrons between carboxyl-GO and $\mathrm{Au}$ electrodes due to the excellent conductivity and electron transfer rate. The carboxyl-GO-based SPR chip exhibited high sensitivity based on the electric field amplification effects of the composite dielectric material. Therefore, the surface electric field could be enhanced by electron transfer, thereby greatly improving the sensitivity of the sensing system. Enhanced electric field intensity was generated around the carboxyl-GO of $63.58 \mathrm{~V} / \mathrm{m}$, and the measured work function was $4.95 \mathrm{eV}$. The results showed that the carboxyl-GO-based SPR biosensor had high sensitivity, affinity and selective ability for PAPPA2 protein with a high association rate constant $(\mathrm{ka})$ of $3.1 \times 10^{9} \mathrm{M}^{-1} \mathrm{~S}^{-1}$ and a limit of detection of $0.01 \mathrm{pg} / \mathrm{mL}$ in spiked human plasma.

Conclusion: The results showed a detection accuracy of protein in spiked plasma of $>90 \%$ compared to PBS buffer, suggesting that the carboxyl-GO-based SPR biosensor could be used in assays of human plasma for early and late gynecological diseases. The future of this technology will be useful for the diagnosis and evaluation of the risk of early maternal preeclampsia and potentially in clinical applications for gestational diseases.

Keywords: carboxyl, graphene oxide, carboxyl-GO, surface plasmon resonance, SPR, pregnancy, associated plasma protein A2, PAPPA2

\section{Introduction}

According to a study by the United Nations Population Fund (UNFPA) in 2017, one of the most important trends of the 21 st century is the rate of population aging and low birth rate, the effects of which will be felt at all levels of society. This trend is most pronounced in Germany, Japan, South Korea, Taiwan, and Singapore, with reported fertility rates in 2018 of $1.46,1.42,1.27,1.13$ and 0.84 (births per woman), 
respectively. ${ }^{2}$ Consequently, "low fertility" and "aging" have been classified as national security concerns in Taiwan, as they will affect the labor force and adversely affect economic development. In order to improve fertility, governments worldwide have proposed various incentives, including subsidizing artificial conception. In addition, prenatal diagnosis and neonatal screening are very important. Neonatal screening of pregnant women may be able to prevent life-threatening complications at an early stage, whereas a diagnosis and treatment after birth may lead to serious health problems. Therefore, the aim of this study was to evaluate the use of a novel type of gestational biomarker for pregnancy-associated plasma protein A2 (PAPPA2).

The potential use of PAPPA2 as a novel biomarker to screen pregnant women for preeclampsia (PE), ${ }^{3,4}$ Down's syndrome, ${ }^{5}$ and HELLP (Hemolytic anemia, Elevated Liver enzymes, and Low Platelet count) syndrome has been reported. ${ }^{6,7}$ The molecular weight of the PAPPA2 antigen is $199 \mathrm{KDa}^{4}$ Clinically, PAPPA2 has been shown to be abundantly expressed in the human placenta and in nonpregnant mammary glands, and to be expressed at lower levels in a variety of other tissues, including the fetal brain, kidneys, and pancreas. ${ }^{8}$ Previous studies have reported that increased levels of PAPPA2 protein in the serum of fetuses with Down's syndrome and in women with PE are strongly associated with sex, and that they can be used as early prognostic markers. Enzyme-linked immunosorbent assays (ELISA) can be used to detect levels of PAPPA2 in the blood serum of women during a normal pregnancy and those with $\mathrm{PE}$, with reported concentrations of more than $71 \mathrm{pg} / \mathrm{mL}$ and $1.25 \mathrm{ng} /$ well, respectively. ${ }^{3,9}$ In addition, the mean concentration of PAPPA2 in Down's syndrome pregnancies between 15 and 20 weeks has been reported to be $82.70 \pm 12.13 \mathrm{ng} / \mathrm{mL}$ compared to $56.35 \pm 3.63 \mathrm{ng} / \mathrm{mL}$ in normal pregnancies. ${ }^{5}$

The development of functionalized graphene oxide (fGO) has led to new developments in the high sensitivity biosensing field, owing to its easy synthesis, unique biocompatibility and affinity characteristics. Due to the unique optical, electrochemical and mechanical properties of graphene-like 2D nanomaterials such as graphene (Gr), ${ }^{10-12}$ reduced graphene oxide (rGO), ${ }^{13,14}$ graphene oxide $(\mathrm{GO})^{15-19}$ and fGO, ${ }^{20-22}$ important developments in the field of biosensors have been achieved. In previous work, we reported for the first time the use of a carboxylGO-based surface plasmon resonance (SPR) chip as an immunoassay. $^{22}$ Carboxyl-GO sheets have abundant
- $\mathrm{COOH}$ functional groups on the surface which increase biomolecule adhesion properties. In particular, carboxylGO modification technology has been widely used in biomedicine, mainly because of its high biocompatibility and affinity, and it has been used in drug carrier ${ }^{23}$ and biofluorescent $^{24}$ applications. An SPR-based sandwich assay involving functionalized gold nanoparticles (AuNPs) has been shown to be able to detect PAPPA2 at levels as low as $3.6 \mathrm{ng} / \mathrm{mL}$ in $30 \%$ blood plasma. $^{25}$ The sensitivity of these detection techniques is greatly limited. However, this PAPPA2 assay technology has not yet been used in rapid diagnostic, ultra-sensitive and high affinity graphene-like nanocomposite-based SPR immunoassays.

In this study, we investigated whether modified carboxyl-GO could enhance the sensitivity and high affinity of SPR immunosensors to allow for the early diagnosis of diseases during pregnancy and detect PAPPA2 biomarkers specifically in human blood plasma. We focused on the pretreatment process, detection methods and methods to reduce interference in non-specific bioactivity for carboxyl-GO-based SPR chips in clinical samples. In addition, we investigated protein adsorption on carboxyl-GO surfaces in an attempt to understand molecular-level mechanisms of immune response interactions with biomaterials. The main advantage of the carboxyl-GO-based SPR chip was in the real-time analysis of disease biomarkers in clinical serum. This technology can be used to specifically recognize PE and other pregnancy-related diseases, and such biosensors can be used to enhance detection due to their high sensitivity and simplicity.

\section{Materials and methods}

\section{Synthesis of carboxyl-go and preparation of sensing chip procedures}

In this study, bioaffinity composites of carboxyl-GO (Figure 1A) were synthesized using the modified Hummer method. In this process, hydroxyl and carbonyl groups were converted to carboxylic acid (R-COOH) by chloroacetic acid (ClCH2CO2H, 99\%, Sigma-Aldrich, USA), which acts as an alkylating agent under basic conditions. ${ }^{23}$ Carboxylate ions are conjugated bases of carboxylic acid, RCOO-, and are negatively charged ions with high ionic adsorption ${ }^{26}$ and enhanced hydrophilic ${ }^{27}$ properties with biomolecules. The fabrication and characterization of biosensor chips with Au film were used as the excited SPR sensing substrate, which immobilized the carboxyl-GO sheets at the Au surface to enhance SPR energy coupling and improve protein binding affinity. 

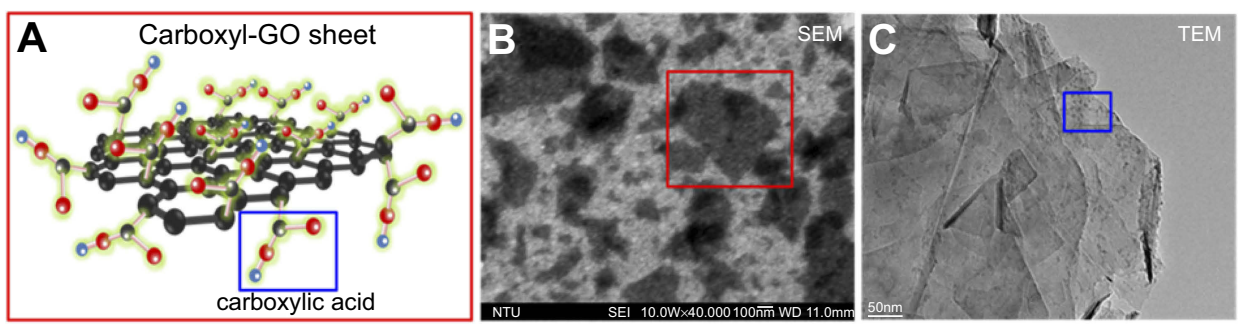

D
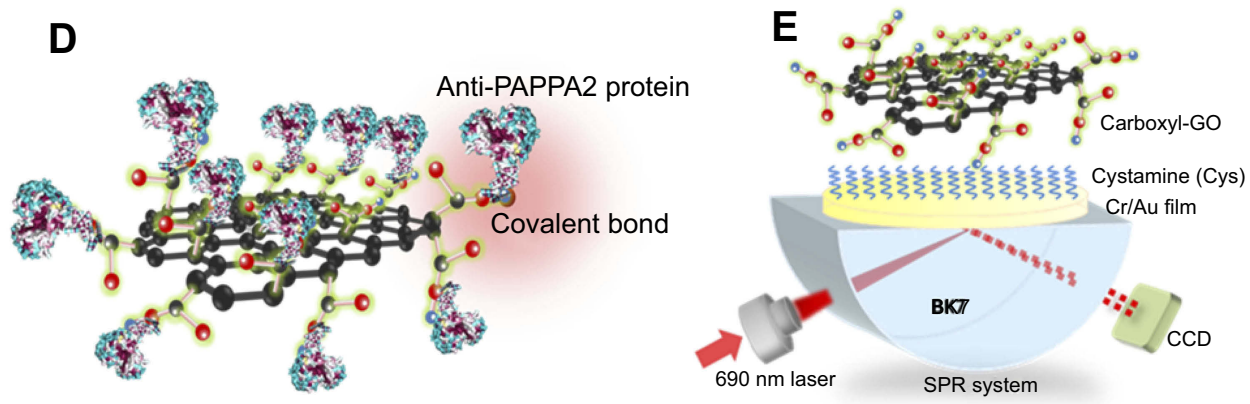

Figure I Chemical modification of graphene-like 2D biosensing materials (A) surface modification of GO with carboxyl-groups (carboxyl-GO), (B) SEM images of carboxylGO sheets, (C) TEM image of carboxyl-GO composites clearly reveals a typical organic matrix-mediated shell structure. (D) Protein immobilization on carboxyl-GO sheets forming highly efficient covalent bonds, (E) SPR sensing system for carboxyl-GO-based immunosensor technology.

Abbreviations: GO, graphene oxide; carboxyl-GO, carboxyl- graphene oxide; CCD, charge-coupled device; SEM, scanning electron microscope; TEM, transmission electron microscope; SPR, surface plasmon resonance.

Cystamine (Cys) $5 \mathrm{mM}$ (cystamine dihydrochloride 98\%, Alfa Aesar, United Kingdom) was used as the linker at room temperature for $24 \mathrm{hrs}$ to bond the Au surface thiol coupling into the carboxyl-GO on the sensing chip. The surface morphology of the functional carboxyl-GO-based SPR chip at the carboxylic acid groups formed an organic compound shell shape as shown in scanning electron microscope (SEM) (Figure 1B) and transmission electron microscope (TEM) images (Figure 1C). The activator was a mixture of N-hydroxysuccinimide (NHS, 98\%, Sigma-Aldrich, USA) and 1-ethyl-3-(3-dimethylaminopropyl)-carbodiimide (EDC, $\geq 98 \%$, Sigma-Aldrich, USA) solution (100 $\mu \mathrm{L}$ of $0.4 \mathrm{M}$ EDC with $100 \mu \mathrm{L}$ of $0.1 \mathrm{M}$ NHS). Surface activation of the carboxyl groups containing carboxyl-GO sheets was achieved by reaction with EDC/NHS. In brief, $200 \mu \mathrm{L}$ of EDC/NHS activation solution was injected into the carboxyl-GO film and stored at $4{ }^{\circ} \mathrm{C}$ for $1 \mathrm{hr}$. The carboxylic acid on the surface of the carboxyl-GO sheets facilitated immobilization of covalent binding with a concentration of anti-PAPPA2 of $25 \mu \mathrm{g} / \mathrm{mL}$ (molecular weight of approximately $150 \mathrm{kDa}$, HPA018430, Sigma-Aldrich, USA), and the mixture was stored at $4{ }^{\circ} \mathrm{C}$ for 3 hrs. Finally, the non-reacted surface active sites were blocked by injecting $200 \mu \mathrm{L}$ of $1 \mathrm{M}$ ethanolamine (EA, $\geq 98 \%$, Sigma-Aldrich, USA) into the carboxyl-GO film at $4{ }^{\circ} \mathrm{C}$ for 30 mins. Cleaning with deionized water was performed after each of these steps. Covalent coupling provided stable and strong binding of the biomolecules to the carboxylGO sheets. Most proteins have amine groups on their surface, so they can be directly conjugated to carboxyl-GO sheets containing reactive groups as shown in Figure 1D. The carboxyl-GO-based SPR sensing chip had a composition of BK7/ $\mathrm{Cr} / \mathrm{Au} / \mathrm{Cys} /$ carboxyl-GO as shown in Figure 1E.

\section{Preparation of the carboxyl-go-based SPR chip to detect PAPPA2 protein in spiked human plasma}

When detecting antigen PAPPA2 (molecular weight of approximately $27 \mathrm{kDa}$, APREST73992, Sigma-Aldrich, USA) protein in spiked human plasma, it is important to consider SPR angle errors and deviations caused by nonspecific and free protein interference. Therefore, we improved the covalent coupling during the immobilization process as shown in Figure 1D. In order to increase the surface resistance to non-specific protein adsorption when covalently coupled carboxyl-GO and anti-PAPPA2 protein were immobilized, bovine serum albumin (BSA, lyophilized powder, $\geq 96 \%$, Sigma-Aldrich, USA) (1 mg/mL for 30 mins) was covalently immobilized to block the carboxyl-GO sheets at areas not coated with anti-PAPPA2 protein. Proteins were blocked on the carboxyl-GO sheets to help prevent non-specific proteins from interacting with the $-\mathrm{COOH}$ surface, especially in complex human blood 
conditions. The remaining unreacted $-\mathrm{COOH}$ bonds were then deactivated using a $1 \mathrm{M}$ EA solution at room temperature for 30 mins. To achieve high selectivity and specificity, the analyte should bind to the bio-receptors (anti-PAPPA2) via specific interactions and not to the chip surface itself to improve pseudo-positive reactions. Therefore, we used three injections of $50 \mathrm{mM} \mathrm{NaOH}$ to remove interfering proteins not covalently bound to clean the chip surfaces. An electrostatic potential will occur at the $-\mathrm{COOH}$ terminal (carboxyl-GO and protein) of the carboxyl-GO-based SPR chip, and electrostatic interactions between the negatively charged carboxyl-GO film of the chip and the protein used as an antibody can significantly influence the SPR results. ${ }^{28}$ In addition, 4\% trisodium citrate was added to the human blood plasma samples as an anticoagulant (No. P9523, Sigma-Aldrich). The addition of BSA to phosphate buffered saline (PBS) in spiked blood plasma could reduce nonspecific interactions, and the addition of Tween-20 (P9416, Sigma-Aldrich, USA) to blood plasma samples could disrupt hydrophobic interactions between analyte and sensor surface. Therefore, in spiked human plasma experiments, the spiked human plasma running buffer (SHPRB) consisted of $20 \%$ plasma $(250 \mu \mathrm{L}), 0.05 \%$ Tween-20 $(30 \mu \mathrm{L})$ and $200 \mu \mathrm{g} / \mathrm{mL}$ BSA mixed in $60 \mathrm{~mL} 1 \mathrm{x}$ PBS. This removed nonspecifically adsorbed proteins while not disrupting the binding of sample PAPPA2 protein to anti-PAPPA2 immobilized on the carboxyl-GO-based SPR chip surface.

\section{Preparation procedure of PAPPA2 protein samples}

To detect PAPPA2 protein in PBS buffer, we used PAPPA2 protein samples diluted to different concentrations (0.01$100 \mathrm{pg} / \mathrm{mL}$ ) using PBS in a volume of $200 \mu \mathrm{L}$. In the nonspecific proteins test, we used different non-specific protein concentrations of $100 \mathrm{pg} / \mathrm{mL}$ each, and a volume of $200 \mu \mathrm{L}$ for BSA, human serum albumin (HSA, $\geq 98 \%$, product number: SRP618, Sigma-Aldrich, USA), human chorionic gonadotropin (hCG, product number:1,297,001, Sigma-Aldrich, USA), human cytokeratin 19 (CK-19, productnumber:NBP2-23,164, Novus Biologicals, USA), and cancer antigen 19-9 (CA-199, product number: MBS173342, MyBioSource, USA) proteins. In addition, in the interference test, we used the five spiked proteins (BSA, HAS, hCG, CK-19, CA-199) at a concentration of $100 \mathrm{pg} / \mathrm{mL}$ each, and a volume of $20 \mu \mathrm{L}$ by mixing with PAPPA2 $(200 \mu \mathrm{L})$ in PBS buffer. To detect PAPPA2 protein in spiked human plasma, the PAPPA2 protein samples were diluted to different concentrations $(0.01-$ $10 \mathrm{ng} / \mathrm{mL}$ ) using SHPRB in a volume of $200 \mu \mathrm{L}$.

\section{Results \\ Choice of materials}

In our previous study, we used carboxyl-GO composites to enhance the sensitivity and high biological affinity of SPR sensing. $^{22,29}$ The SPR of noble metal thin films has been widely used in biosensing. For example, silver (Ag) is preferred for its narrow resonance curve which results in a high signal to noise ratio (SNR), and Au film has the advantage of having good chemical resistance. Ag and $\mathrm{Au}$ bimetallic thin film has been frequently used to improve the resolution and adhesion in biosensing applications. Even though Ag film can have a sharper dip than $\mathrm{Au}$ as an SPR sensor, it is known that Ag can easily be oxidized in buffer resulting in a degraded performance. We hypothesized that the alloy/GO structure may have a sharper dip than $\mathrm{Au} / \mathrm{GO}$ in biosensing applications.

\section{Analysis of optical absorption and interface potential of the carboxyl-go-based SPR chip}

Attenuated total-reflectance Fourier transformation infrared spectroscopy (ATR-FTIR) was used to examine the modification of carboxyl-GO films and the covalent functionalization of carboxyl-GO binding with anti-PAPPA2 protein and various oxygenated species (Figure 2A). In the FTIR spectrum of GO and carboxyl-GO, the absorption peaks indicated $\mathrm{O}-\mathrm{H}$ stretching vibrations at $3336 \mathrm{~cm}^{-1}, \mathrm{C}-\mathrm{H}$ stretching in aldehydes at $2925-2859 \mathrm{~cm}^{-1}, \mathrm{C}=\mathrm{O}$ stretching in carboxylic acids at $1738 \mathrm{~cm}^{-1}$, and $\mathrm{C}-\mathrm{O}$ stretching in alcohols at $1066 \mathrm{~cm}^{-1}$. The carboxyl-GO spectrum peak was clearly observed, and it was apparent that $\mathrm{OH}$ at $3336 \mathrm{~cm}^{-1}$ resulted in a decrease, and $-\mathrm{COOH}$ at $1738 \mathrm{~cm}^{-1}$ resulted in an increase. However, after chloroacetic acid was grafted onto the surface of GO, the O-H stretch in phenol (H-bonded) peaks disappeared. In addition, a $-\mathrm{COOH}$ peak was observed at $1738 \mathrm{~cm}^{-1}$, which originated from $\mathrm{C}=\mathrm{O}$ stretching in carboxylic acids. This indicated that the $-\mathrm{COOH}$ groups from the hydroxyl $(-\mathrm{OH})$, epoxide $(-\mathrm{O})$ and ester groups had been converted to carboxylic groups $(-\mathrm{COOH})$ and had become attached covalently to the GO surface during the chloroacetic acid reaction. In addition, the FTIR peaks of GO and carboxylGO immobilized anti-PAPPA2 protein seen at 1660 and $1644 \mathrm{~cm}^{-1}$ were amide compounds mainly involving $\mathrm{C}=\mathrm{O}$ 

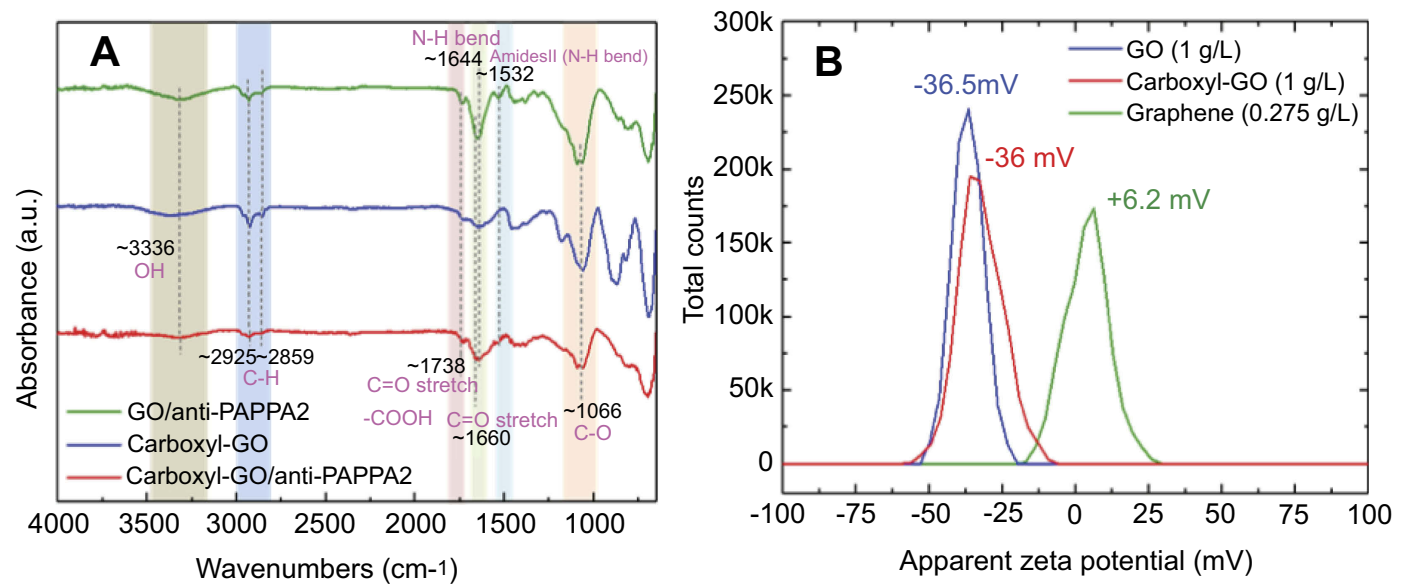

Figure 2 Analysis of the sensing material surface chemical structure with regards to FTIR spectra and zeta potential properties. (A) Comparison of FTIR spectra of covalent bonds between the GO and carboxyl-GO with anti-PAPPA2 proteins. (B) Comparison of zeta potential of GO and carboxyl-GO sheets dispersed in water and graphene sheets dispersed in ethanol solvent.

Abbreviations: FTIR, Fourier transform infrared spectroscopy; GO, graphene oxide; carboxyl-GO, carboxyl-graphene oxide; PAPPA2, pregnancy-associated plasma protein A2.

stretching vibrations, and the $1532 \mathrm{~cm}^{-1}$ peak was an amide compound involved in the coupling of bending vibrations of $\mathrm{N}-\mathrm{H}$ and stretching vibrations of $\mathrm{C}-\mathrm{N}$ bonds. ${ }^{30} \mathrm{GO}$ sheets have hydrophilic groups (epoxy bridges, hydroxyl groups, carboxyl groups, and carbonyl groups, etc.), and these polar groups can provide electroactive sites on GO sheets that are reasonably energetically favorable and increase density and dispersion rates. We estimated the zeta potentials of the GO, graphene and carboxyl-GO sheets as shown in Figure 2B. $\mathrm{GO}$ is negatively charged in an aqueous solution due to the various oxygenated groups on its surface. The $\mathrm{x}$-axis shows that the zeta potential of the GO sheets was $-36.5 \mathrm{mV}$ at $\mathrm{pH}$ 3.5. After modification, and the zeta potential of carboxyl$\mathrm{GO}$ still remained in the range of $-36 \mathrm{mV}$ at $\mathrm{pH} 4.2$, indicating that carboxyl-GO had adequate negative charges on the surface with good colloidal stability. ${ }^{31}$ In addition, the zeta potential of a $90 \%$ single layer ratio of graphene sheets was $+6.2 \mathrm{mV}$ at $\mathrm{pH} 6$ with dispersion in ethanol solvent. The lack of oxygen functional groups on the surface chemistry of graphene materials results in positively charged graphene sheets. ${ }^{32}$ The results showed that the surface charge characteristics controlled electrostatic repulsion between the negatively charged GO sheets, which in turn affected the interlayer spacing of carboxyl-GO.

\section{Analysis of uv-vis spectra and cyclic voltammetry of the carboxyl-go-based SPR chips}

Figure $3 \mathrm{~A}$ shows the UV-vis spectra of graphene sheets (single layer ratio $<90 \%$, average diameter size of $1 \mu \mathrm{m}$ ),
GO sheets (single layer ratio $<80 \%$, average diameter size $<1 \mu \mathrm{m}$ ) and carboxyl-GO sheets (single layer ratio $<80 \%$, average diameter size $<1 \mu \mathrm{m}$ ) dispersed in water. The UVvis spectrum of $0.1 \mathrm{~g} / \mathrm{L} \mathrm{GO}$ exhibited strong absorption peaks at 233 and $300 \mathrm{~nm}$, corresponding to $\mathrm{C}=\mathrm{C}\left(\pi \rightarrow \pi^{*}\right)$ and $\mathrm{C}=\mathrm{O}\left(\mathrm{n} \rightarrow \pi^{*}\right)$ bonds, respectively. ${ }^{33}$ As expected, graphene and carboxyl-GO exhibited strong bands centered at $233 \mathrm{~nm}$, which were attributable to $\pi \rightarrow \pi^{*}$ transitions of aromatic $\mathrm{C}-\mathrm{C}$ bonds, however they became broader compared to those of GO. At $300 \mathrm{~nm}$ there was no significant $\mathrm{n} \rightarrow \pi^{*}$ transitions peak, since some of the oxygen atoms had been reduced. Figure $3 \mathrm{~B}$ shows the effect of scan rate on the cyclic voltammogram $(\mathrm{CV})$ response of the modified electrode. Carboxyl-GO showed a systematic decrease in current in the oxidation peak and reduction peak potential as the rate decreased. The CVs for the behavior of bare $\mathrm{Au}$ and carboxyl-GO chips were used for the characterization curves obtained at a potential ranging from 0.0 to $0.7 \mathrm{~V}$ and scan rates of 10,30 and 60 $\mathrm{mV} \cdot \mathrm{s}^{-1}$ in $0.1 \mathrm{M} \mathrm{KCl}$ solution that also contained $2 \mathrm{mM}$ $[\mathrm{Fe}(\mathrm{CN}) 6]^{3-/ 4-}$. The results showed a pair of reversible redox peaks at $0.268 \mathrm{~V}$ and $0.376 \mathrm{~V}$ for the bare $\mathrm{Au}$ chip and at $0.244 \mathrm{~V}$ and $0.358 \mathrm{~V}$ for the carboxyl-GO chip. The carboxyl-GO chip yielded lower oxidation and reduction peak currents than the bare $\mathrm{Au}$ chip, representing the remains of oxygen-containing functional groups on the surface of GO leading to decreased electron transfer capability. The separation values of oxidation and reduction peak potentials $\left(\left|\Delta \mathrm{E}_{\mathrm{p}}\right|=\left|\mathrm{E}_{\mathrm{pa}}-\mathrm{E}_{\mathrm{pc}}\right|\right)$ were 108 and $114 \mathrm{mV}$ for the bare Au and carboxyl-GO chips, respectively. The 

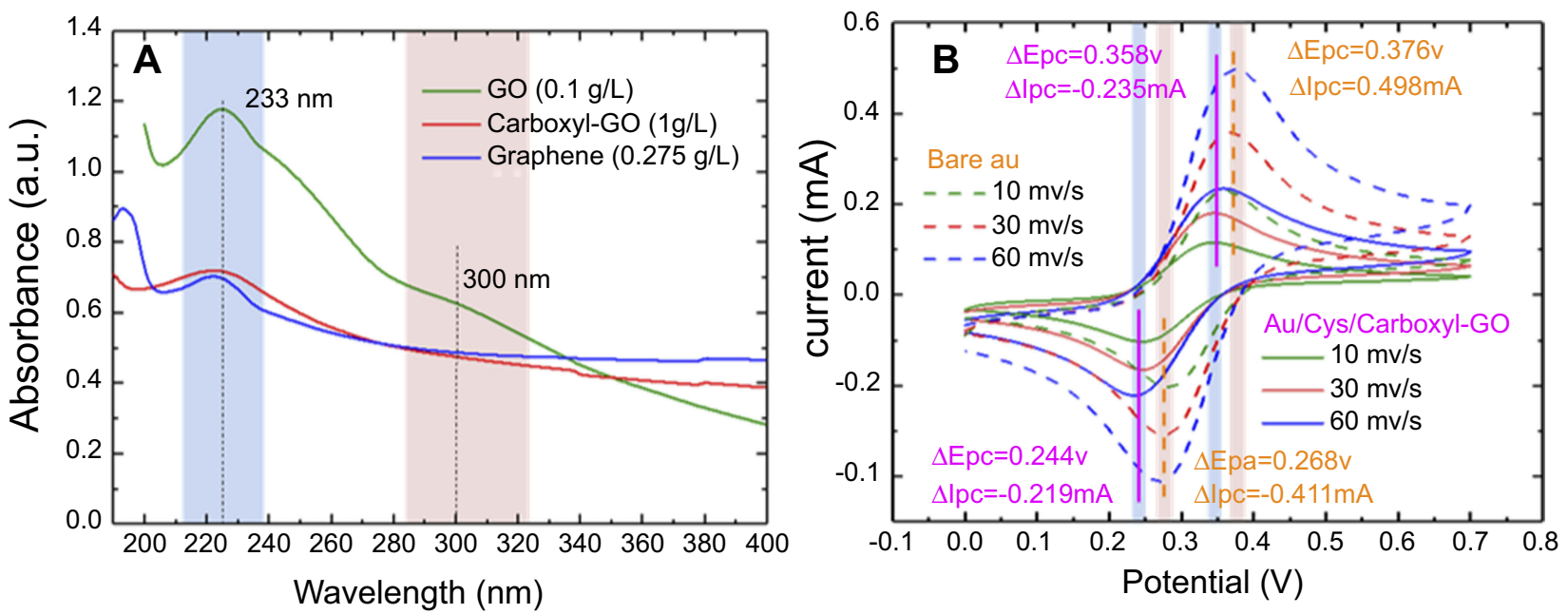

Figure 3 Analysis of the sensing material surface chemical structure with regards to optical and electrochemical properties. (A) Comparison of UV-vis absorbance spectra of GO, carboxyl-GO and graphene sheets dispersed in water. (B) Cyclic voltammetry analysis of different scan rates of carboxyl-GO and bare Au chips.

Abbreviations: UV-vis, ultraviolet-visible; carboxyl-GO, carboxyl-graphene oxide; Au, gold.

ratio of oxidation-to-reduction peak currents $\left(\mathrm{I}_{\mathrm{pa}} / \mathrm{I}_{\mathrm{pc}}\right)$ was close to unity, the reduction peak current appeared at $0.235 \mathrm{~mA}$, and the oxidation peak current appeared at $-0.219 \mathrm{~mA}$ for the carboxyl-GO chip and at a scan rate of $60 \mathrm{mV} \cdot \mathrm{s}^{-1}$. The $\mathrm{CV}$ measurements were made using a CHI model 604D workstation (CH Instruments, Austin, TX, USA).

\section{Measurement and numerical calculation of the carboxyl-go based SPR multilayer structure}

Figure 4 shows the measurement and numerical calculation of the carboxyl-GO-based SPR multilayer structure interfaces. Figure 4A shows the results of SPR angular reflectivity curves for ATR Kretschmann-configuration. The resonance angle of the SPR curve was the external angle $\left(\theta_{\text {ext }}\right)$. This multilayer structure of the chip was composed of BK7/chromium $\left(\mathrm{d}_{\mathrm{Cr}}=2 \mathrm{~nm}\right) /$ gold $\left(\mathrm{d}_{\mathrm{Au}}=47 \mathrm{~nm}\right) / C y \mathrm{~s} /$ carboxyl-GO/air. The wavelength of the incident light was 600 to $700 \mathrm{~nm}$, and the wavelength interval was $10 \mathrm{~nm}$. In the experimental results, it was clear that the resonance SPR angle became smaller as the incident wavelength increased. The measured results of a carboxyl-GO chip with corresponding incident wavelengths of $600,610,620,630,640,650,660,670,680$, 690 , and $700 \mathrm{~nm}$ showed resonance angles of $36.3^{\circ}, 35.8^{\circ}$, $35.3^{\circ}, 35.1^{\circ}, 34.8^{\circ}, 34.7^{\circ}, 34.5^{\circ}, 34.2^{\circ}, 34.0^{\circ}, 33.8^{\circ}$, and $33.7^{\circ}$, respectively.

Figure 4B, C and D show the data of the carboxyl-GObased SPR multilayer structure for the coupling effect calculated using Fresnel's equations. The BK7/Cr/Au/ Cys/carboxyl-GO multilayer structure produced efficient numerical calculations of the SPR curve equation using a series of incident wavelengths in transverse magnetic (TM) polarization. ${ }^{34}$ We used the refractive index (n) and extinction coefficient (k) at a wavelength of $690 \mathrm{~nm}$ corresponding to $\mathrm{Cr}$, $\mathrm{Au}$, and $\mathrm{Cys}$ films, and obtained 3.797 $+\mathrm{i} 4.368,0.116+\mathrm{i} 3.817$, and $1.45+\mathrm{i} 0$, respectively. ${ }^{35}$ The use of $1 \mathrm{~g} / \mathrm{l}$ concentration of carboxyl-GO resulted in a film with a thickness of $3 \mathrm{~nm}$ of a self-assembled monolayer (SAM) composition. ${ }^{36}$ Using these parameters and the measurement results in Figure 4A in Fresnel's equations for a multilayer theory, the carboxyl-GO film refractive index was $1.673 .{ }^{29}$ All numerical calculations of the resonance angle of the SPR curve were internal angles $\left(\theta_{\text {int }}\right)$. Figure $4 \mathrm{~B}$ shows that the calculated propagation momentum of the SPR dispersion curves included incident wavelengths of $600-700 \mathrm{~nm}$ versus incident angles of $35^{\circ}$ $55^{\circ}$ for the reflectance dips. Dispersion curves were used to evaluate the sensing sensitivity of the carboxyl-GObased SPR coupled parameters for full width at half maximum (FWHM), minimum reflection intensity $\left(\mathrm{R}_{\min }\right)$ and SPR angle shift. The position of the reflectance dips at an incident wavelength of 670-700 nm showed a good FWHM in narrow, sharp and high resolution SPR angle shifts in the dispersion curves. The $\mathrm{R}_{\min }$ was approximately $0.185 \%$ for a resonance angle of $43.85^{\circ}$ at an incident wavelength of $690 \mathrm{~nm}$. Figure 4C shows the SPR absorption curve for an SP resonance angle of $43.81^{\circ}$ with a $\mathrm{BK} 7 / \mathrm{Cr} / \mathrm{Au} /$ carboxyl-GO multilayer structure. The 

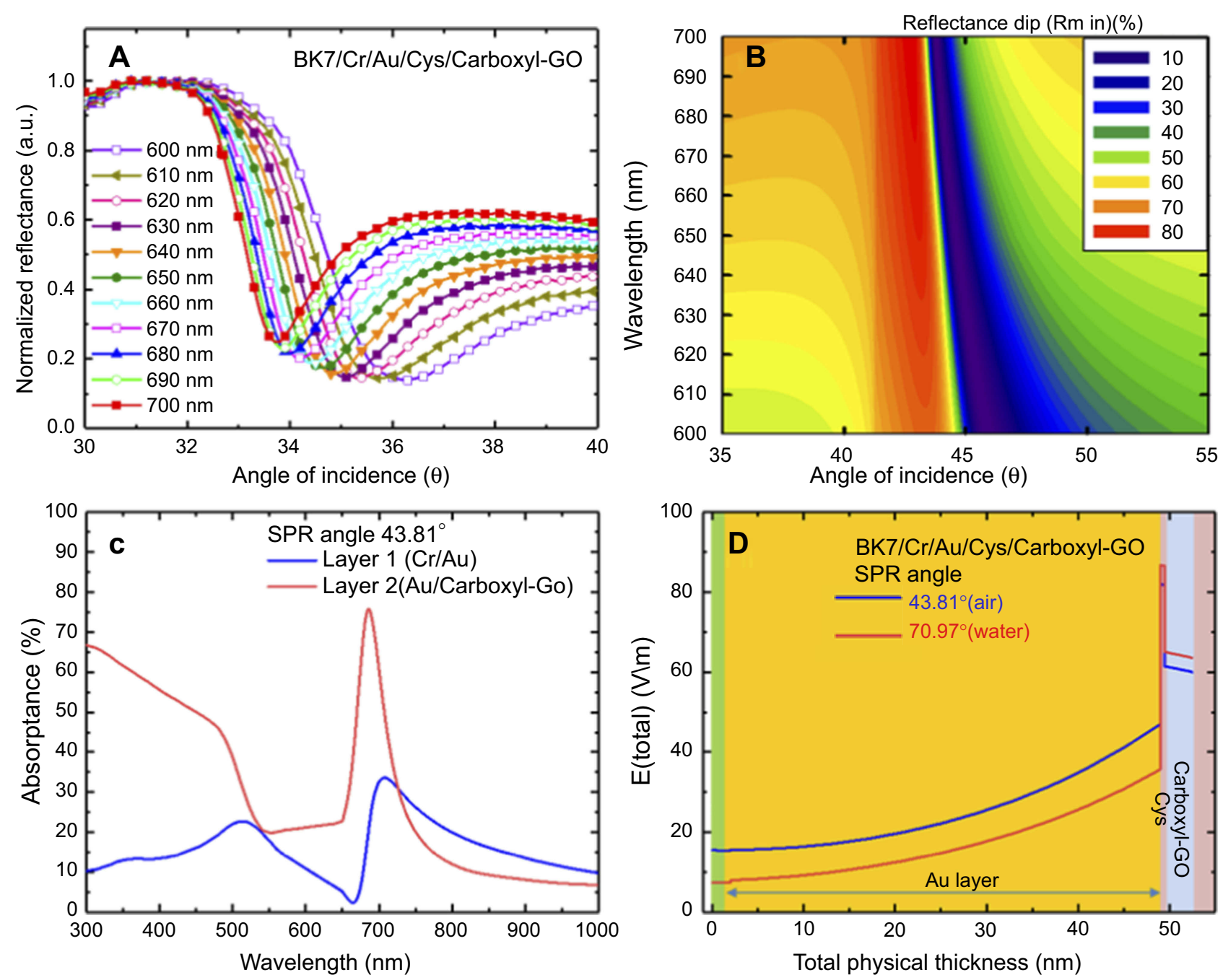

Figure 4 Experimental and numerical analyses of sensitivity-related characteristic curves of BK7/Cr/Au/Cys/carboxyl-GO-based SPR biosensors in air medium. (A) Measured SPR reflectivity curves at different wavelengths vs incident angle. (B) Theoretical calculation of the dispersion relation of the SPR modes. (C) Calculation of the optical absorption spectra of the interfaces layer by layer. (D) Electric field intensity distribution across the inside medium, Au layer and carboxyl-GO layer. Abbreviations: SPR, surface plasmon resonance; Cr, chromium; Au, gold; Cys, cystamine; GO, graphene oxide; carboxyl-GO, carboxyl-graphene oxide.

largest absorption peak of the Au/carboxyl-GO interface for layer 2 was at a wavelength of $690 \mathrm{~nm}$.

To further clarify the origin of the enhanced sensitivity, we calculated the interface electric field intensity distribution of the $\mathrm{BK} 7 / \mathrm{Cr} / \mathrm{Au} / \mathrm{Cys} /$ carboxyl-GO multilayer structure chip as shown in Figure 4D. The results showed that the electric field intensity was $63.58 \mathrm{~V} / \mathrm{m}$ at an SP resonance angle of $70.97^{\circ}$ for the liquid interfaces, and $60.04 \mathrm{~V} / \mathrm{m}$ at an $\mathrm{SP}$ resonance angle of $43.81^{\circ}$ for the air interfaces. These results showed that the reason for the enhanced sensitivity was an increase in the evanescent field due to increases in oxygen and carboxyl media of the carboxyl-GO sheets. As seen in Figure 4D, enhanced sensitivity and stability of the carboxyl-GO-based SPR biosensors showed a low coupling rate of $<650 \mathrm{~nm}$ wavelength. Therefore, the oxygen and carboxyl contents of the carboxyl-GO sheets could be adjusted to improve plasmon energy coupling efficiency from more than $650 \mathrm{~nm}$ to near-infrared, and could therefore be used to improve and control the sensing sensitivity mechanism.

\section{Photoelectron spectroscopy of carboxyl-go surface elements and electronic work function}

The evolution of the surface chemistry of carboxyl-GO was analyzed using X-ray photoelectron spectroscopy (XPS) and ultra-violet photoelectron spectroscopy (UPS), which revealed the surface chemistry binding energy of surface elements and electronic work function (Figure 5). Figure 5A shows the XPS survey spectra of the Au/Cys/carboxyl-GO chip, which 

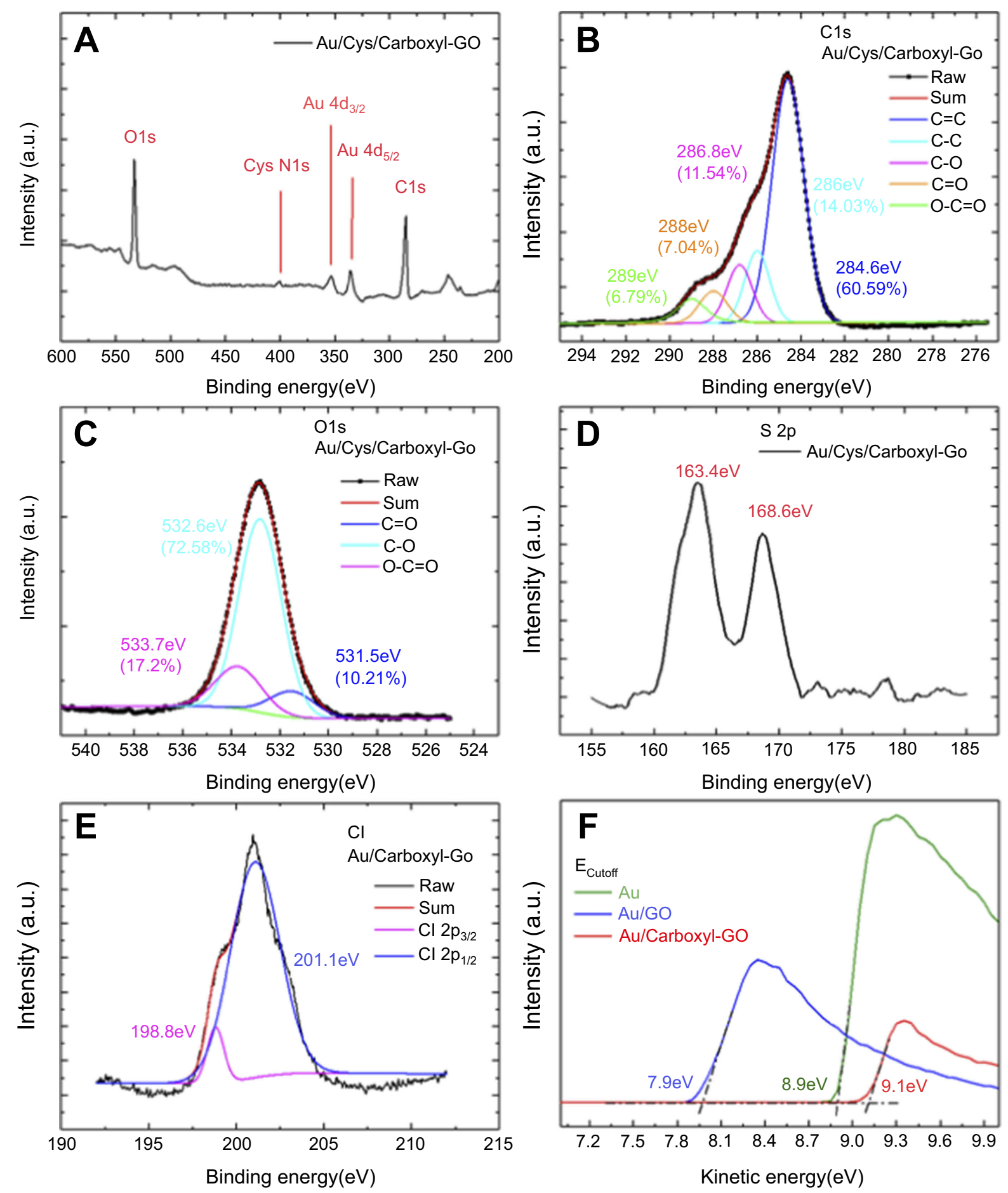

Figure 5 Characteristics of high-resolution XPS and UPS data of the Au/Cys/Carboxyl-GO chip. (A) Survey XPS spectra. (B) XPS of C Is spectra. (C) XPS of O Is spectra. (D) XPS of S-bond spectra. (E) XPS of Cl-bond spectra. (F) UPS curves of different chip surfaces.

Abbreviations: XPS, X-ray photoelectron spectroscopy; UPS, ultra-violet photoelectron spectroscopy; Carboxyl-GO, carboxyl-graphene oxide; Au, gold; Cys, cystamine.

exhibited peaks associated with $\mathrm{C} 1 \mathrm{~s}, \mathrm{O} 1 \mathrm{~s}, \mathrm{Cys} \mathrm{N} 1 \mathrm{~s}, \mathrm{Au} 4 \mathrm{~d}_{3 / 2}$ and $\mathrm{Au} 4 \mathrm{~d}_{5 / 2}$. High-resolution spectra in the region of the $\mathrm{C} 1 \mathrm{~s}$ characteristic peak for the $\mathrm{Au} / \mathrm{Cys} /$ carboxyl-GO chip are shown in Figure 5(b). There were five peaks located at 284.6, 286, 286.8, 288 and $289 \mathrm{eV}$, which were due to $\mathrm{C}=\mathrm{C}$
(60.59\%), $\mathrm{C}-\mathrm{C}(14.03 \%), \mathrm{C}-\mathrm{O}(11.54 \%), \mathrm{C}=\mathrm{O}(7.04 \%)$ and $\mathrm{O}-\mathrm{C}=\mathrm{O}(6.79 \%)$, respectively.

Figure $5 \mathrm{C}$ and D show XPS analyses of the $\mathrm{O} 1 \mathrm{~s}$ and $\mathrm{S}$ $2 p$ characteristic peaks for the $\mathrm{Au} / \mathrm{Cys} /$ carboxyl-GO chip. As shown in Figure 5C, the O 1s XPS spectra of the 
$\mathrm{Au} / \mathrm{Cys} / \mathrm{GO}-\mathrm{COOH}$ chip clearly indicated a considerable degree of oxygen, with three components at 531.5, 532.6 and $533.7 \mathrm{eV}$ corresponding to $\mathrm{C}=\mathrm{O}(10.21 \%), \mathrm{C}-\mathrm{O}$ $(72.58 \%)$ and $\mathrm{O}-\mathrm{C}=\mathrm{O}(17.2 \%)$, respectively. ${ }^{37,38} \mathrm{We}$ used XPS analysis of sulfur atoms to assess the $\mathrm{Au} / \mathrm{Cys} /$ carboxyl-GO chip. The results revealed that sulfur existed in two forms as seen in the S 2 p spectrum for adsorption of the cystamine linker for the thiol group attached to the $\mathrm{Au}$ surface and the amino groups covalently bonded to the carboxyl-GO sheets (Figure 5D). This showed sulfur functionality, including components at 163.4 and $168.6 \mathrm{eV}$ due to the sulfur atoms of cystamine being involved in the formation of sulfhydryl groups. ${ }^{39}$ Successful carboxylGO sheets were observed with carboxyl bonds to the surface of the Au film. The XPS high-resolution chlorine $2 p$ spectra depicted in Figure 5E show two main separate peaks for $\mathrm{Cl} 2 \mathrm{p}_{3 / 2}$ and $\mathrm{Cl} 2 \mathrm{p}_{1 / 2}$ for the surface binding energy of various components at $198.8 \mathrm{eV}$ and $201.1 \mathrm{eV}$, respectively. The presence of chlorine in the XPS spectra experimental results confirmed that chloroacetic acid had modified carboxyl-GO. ${ }^{40}$

Figure $5 \mathrm{~F}$ shows the work functions $(\Phi)$ of $\mathrm{GO}$ and carboxyl-GO as measured by UPS using a VG CLAM4 surface analysis system. A He (I) source $(21.21 \mathrm{eV})$ was used as a non-monochromatic illumination for the UPS measurements. ${ }^{41}$ The results showed that changes in GO and carboxyl-GO work functions depended on the oxygen molecule coverage and speciation, and on the film thickness and flake size. Because of differences in work functions between GO, carboxyl-GO and $\mathrm{Au}$, the surface electric field could be enhanced by electron transfer, thereby greatly improving the sensitivity of the sensing system.

The $\Phi_{\text {sys }}$ for a given multilayer material surface was defined by the difference:

$$
\Phi_{\text {sys }}=h v+E_{C}-E_{F}
$$

where $\mathrm{hv}$ is the photon source of $21.21 \mathrm{eV}, \mathrm{E}_{\mathrm{C}}$ is the kinetic energy cut-off obtained by subtracting the binding energy as shown in Figure $5 \mathrm{~F}$, and $\mathrm{E}_{\mathrm{F}}$ is the Fermi level (electrochemical potential of electrons) inside the material.

The measured parameters were an $\mathrm{E}_{\mathrm{F}(\mathrm{Au})}$ of $20.65 \mathrm{eV}$ and $\mathrm{E}_{\mathrm{C}(\mathrm{Au})}$ of $8.9 \mathrm{eV}$. As $\Phi_{(\mathrm{Au})}$ was known to be $5.1 \mathrm{eV}$, the calculated value of $\Phi_{\text {sys }}$ was $9.46 \mathrm{eV}$. The system basic work function deviation was $\Phi_{\mathrm{sys}}-\Phi_{(\mathrm{Au})}=4.36 \mathrm{eV}$ in the spectrometer threshold of the UPS spectra. The surface properties of $\mathrm{GO}$ were an $\mathrm{E}_{\mathrm{C}(\mathrm{Au} / \mathrm{GO})}$ of $7.9 \mathrm{eV}, \mathrm{E}_{\mathrm{F}(\mathrm{Au} / \mathrm{GO})}$ of $20.85 \mathrm{eV}$, and $\Phi_{(\mathrm{GO})}$ of $3.9 \mathrm{eV}$. According to these calculations, the carboxyl-GO chip surface properties were an $\mathrm{E}_{\mathrm{C}(\mathrm{Au} / \mathrm{GO}-\mathrm{COOH})}$ of $9.1 \mathrm{eV}, \mathrm{E}_{\mathrm{F}(\mathrm{Au} / \mathrm{GO}-\mathrm{COOH})}$ of $21 \mathrm{eV}$, and $\Phi_{(\mathrm{GO}-\mathrm{COOH})}$ of $4.95 \mathrm{eV}$.

\section{Analysis and detection of binding interactions of PAPPA2 proteins in PBS buffer}

Figure 6A shows the SPR immunoassay of time sensorgram and kinetic analysis for an anti-PAPPA2 concentration of $25 \mu \mathrm{g} / \mathrm{mL}$ on the immobilized carboxyl-GO surface to assay PAPPA2 protein at a $60 \mu \mathrm{L} / \mathrm{min}$ flow rate of PBS running buffer, in which the black dashed line indicates quantitative kinetic assays and fitting. In binding SPR equilibrium angle $\left(\theta_{\text {eq }}\right)$ analysis, the real-time SPR signal at equilibrium time $\left(\mathrm{T}_{\mathrm{eq}}\right)$ was $300 \mathrm{~s}$. Time sensorgrams of the SPR angle response at a steady state versus different PAPPA 2 concentrations used for the binding assay showed SPR angle shifts for PAPPA2 protein concentrations of $0.01,0.1,1,10,100 \mathrm{pg} / \mathrm{mL}$ of $1.49,4.54,9.73,12.65$, and $18.64 \mathrm{~m}$, respectively.

Nonlinear regression for the most commonly used Langmuir model of kinetic-binding curves for 1:1 steady state interactions of antigen-antibody recognition was used to estimate rate constants. The data shown were generated for the label-free kinetic binding of PAPPA2 proteins at different concentrations. The equilibrium dissociation constant was calculated from the $\mathrm{K}_{\mathrm{D}}$ obtained by fitting a plot of response at $\theta_{\mathrm{eq}}$ against the concentration as shown in Figure 6B. In kinetic analysis, the calculated equilibrium association rate constant $\left(\mathrm{k}_{\mathrm{a}}\right)$ and dissociation rate constant $\left(\mathrm{k}_{\mathrm{d}}\right)$ were used to determine $\mathrm{K}_{\mathrm{D}}$ of two kinetic constants through the defining relationship $\mathrm{k}_{\mathrm{a}} / \mathrm{k}_{\mathrm{d}} \cdot{ }^{42}$ The experimental results of $K_{D}$ showed binding interactions at a $60 \mu \mathrm{l} / \mathrm{min}$ flow rate of four different concentrations of $0.1,1,10$, and $100 \mathrm{pg} / \mathrm{mL}$, corresponding to $\mathrm{K}_{\mathrm{D}}$ values of $25.4 \mathrm{pM}, 8 \mathrm{nM}$, $1.927 \mathrm{pM}$ and $1.566 \mathrm{pM}$, respectively. The results of the carboxyl-GO-based SPR chip showed a significantly small dissociation constant. As shown in Figure 6B, the kinetic fits of $\mathrm{k}_{\mathrm{a}}$ at a $60 \mu \mathrm{L} / \mathrm{min}$ flow rate for concentrations of 0.1 , 1,10 , and $100 \mathrm{pg} / \mathrm{mL}$ corresponded to $1.0 \times 10^{10}, 4.0 \times 10^{11}$, $1.01 \times 10^{9}$, and $1.04 \times 10^{9} \mathrm{M}^{-1} \mathrm{~s}^{-1}$, respectively. The key findings of this investigation were the excellent sensitivity and high affinity of the carboxyl-GO chip.

The specificity of an immunoassay depends not only on the binding properties of the antigen, but also on the composition of the antibody and its sensing carboxyl-GO chip. To investigate the interference effects in the detection of various 

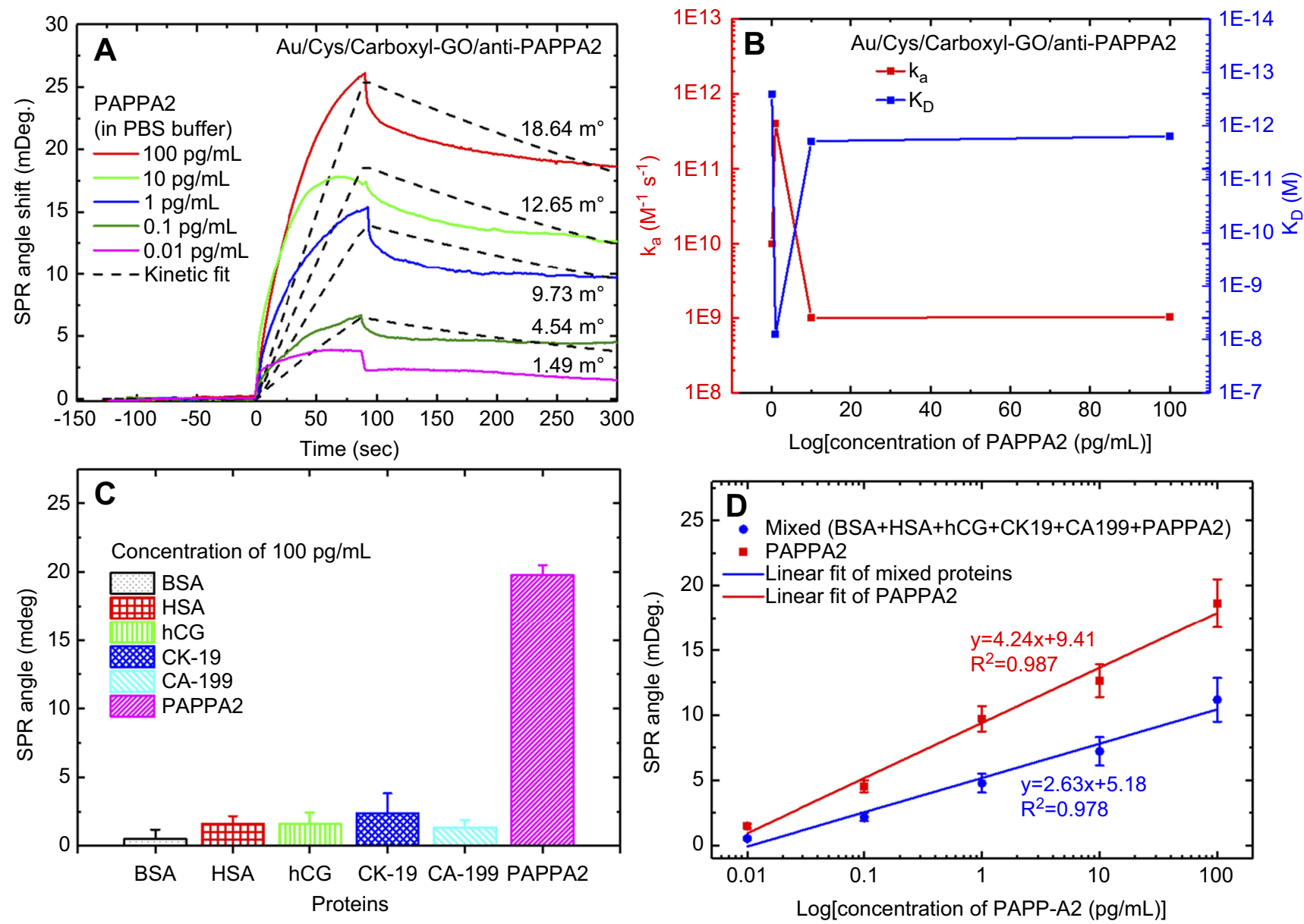

Figure 6 Quantitative analysis of the SPR sensorgram revealed the immune responses to anti-PAPPA2 proteins at different concentrations. (A) Sensorgram of different concentrations of PAPPA2 antibodies. (B) Binding affinity and kinetic analysis of the immune response interactions of the dissociation constant ( $\left.\mathrm{K}_{\mathrm{D}}\right)$ and association rate $\left(\mathrm{k}_{\mathrm{a}}\right)$. (C) Plots of SPR angle shift versus five different interfering proteins and PAPPA2. The assay had high specificity with PAPPA2 against bio-interferences. (D) Calibration curves for the detection of PAPPA2 concentrations and the five spiked interfering proteins.

Abbreviations: SPR, surface plasmon resonance; PAPPA2, pregnancy-associated plasma protein A2.

proteins, we performed specificity assays on anti-PAPPA2 with five different proteins at a concentration of $100 \mathrm{pg} / \mathrm{mL}$ and a flow rate of $60 \mu \mathrm{L} / \mathrm{min}$ as shown in Figure 6C. Among these non-specific proteins, the measured SPR angles at a concentration of $100 \mathrm{pg} / \mathrm{mL}$ each and a volume of $200 \mu \mathrm{L}$ for BSA, HSA, hCG, CK-19, and CA-199 proteins were -0.014 , $2.17,2.45,3.82$, and $1.67 \mathrm{~m}^{\circ}$, respectively. This assay had a high specificity for anti-PAPPA2 with a PAPPA2 binding site under a complex environment with many ionic and neutral analytes and no binding reaction with the other interfering proteins.

There was a linear change in SPR angle as a function of PAPPA2 concentration with a PAPPA2 concentration ranging from 0.01 to $100 \mathrm{pg} / \mathrm{mL}$, and a detection limit (LOD) of $0.01 \mathrm{pg} / \mathrm{mL}$ as shown in Figure 6D. The linear regression equation of the calibration curve was $\mathrm{y}=4.24 \mathrm{x}+9.41$ with $\mathrm{R}^{2}=0.987$ for the immunoassay in PBS buffer, where $\mathrm{x}$ is the concentration of anti-PAPPA2 and $\mathrm{y}$ is the SPR angle shift. The five spiked proteins were used at a concentration of $100 \mathrm{pg} / \mathrm{mL}$ each, and a volume of $20 \mu \mathrm{L}$ by mixing with PAPPA2 in PBS buffer. Linearly fitting the data with the steady state equilibrium angle showed a good correlation between anti-PAPPA2 and PAPPA2 of $y=2.63 x+5.18$ with $\mathrm{R}^{2}=0.978$ for the five different proteins. The error bars represent three replicate measurements. Table 1 shows the assay and calculated affinity for kinetic interactions of PAPPA2 proteins in PBS buffer. The stability of the resonance angle of the carboxyl-GO-based SPR chip in buffer to detect the repeated regeneration of PAPPA2 protein was within $10 \%$. The storage stability of the biosensor was up to $80 \sim 85 \%$ after storage for 30 days in a refrigerator at $4{ }^{\circ} \mathrm{C}$.

In terms of immobilization proteins, an antibody often cannot control its modification orientation, which may lead to large errors or poor sensitivity of the analysis results. 
Table I Affinity and assay for kinetic interactions of PAPPA2 proteins in PBS buffer

\begin{tabular}{|l|l|l|l|}
\hline $\begin{array}{l}\text { PAPPA2 } \\
(\mathbf{p g} / \mathbf{m L})\end{array}$ & SPR angle $\left(\mathbf{m}^{\circ}\right)$ & $\mathbf{k}_{\mathbf{a}}\left(\mathbf{M}^{-1} \mathbf{S}^{-1}\right)$ & $\mathbf{K}_{\mathbf{D}}(\mathbf{M})$ \\
\hline 0.01 & 1.49 & $\mathrm{ND}$ & $\mathrm{ND}$ \\
0.1 & 4.54 & $1.0 \times 10^{10}$ & $2.54 \times 10^{-13}$ \\
1 & 9.73 & $4.0 \times 10^{11}$ & $8.0 \times 10^{-9}$ \\
10 & 12.65 & $1.01 \times 10^{9}$ & $1.93 \times 10^{-12}$ \\
100 & 18.64 & $1.04 \times 10^{9}$ & $1.56 \times 10^{-12}$ \\
\hline
\end{tabular}

Abbreviations: PAPPA2, pregnancy-associated plasma protein A2; PBS, phosphate buffered saline; $\mathrm{K}_{\mathrm{D}}$, dissociation constant; $\mathrm{k}_{\mathrm{a}}$, association rate; ND, not determined.

Kinetic analysis using an SPR technique for mathematical (between antibodies or between antibody antigens) and inter-molecular force analysis (between ions and compounds) is therefore advantageous. We calculated the dissociation constant, and determined the intensity of the action based on the degree of change of the complex formed between the molecules. In previous work, ${ }^{29}$ we reported the results of traditional SPR and carboxyl-GObased SPR chips with regards to antibody concentration immobilization conditions used to measure molecular interactions and non-specific adhesion between chip surfaces. The results showed that the carboxyl-GO-based SPR chip could amplify the angle response by 6.2 times and enhance the high affinity constant (KA) by 93 times compared to carboxyl-GO-based SPR and traditional SPR chips. In the discussion of immobilization and qualitative analysis, it is clear that a carboxyl-GO-based SPR chip is superior to a traditional chip with regards to interaction with protein molecules. This proves that the steric hindrance of a carboxyl-GO-based SPR chip is superior to a conventional chip. The carboxyl-modification was confirmed, and the orientation steric hindrance had good bonding ability.

\section{Analysis and detection of PAPPA2 protein in spiked human plasma}

We then analyzed the detection of PAPPA2 protein in spiked human plasma with the carboxyl-GO chip. Figure 7A shows the SPR sensorgrams of immunoassays for anti-PAPPA2 $(25 \mu \mathrm{g} / \mathrm{mL})$ and PAPPA2 $(10 \mathrm{pg} / \mathrm{mL}, 100 \mu \mathrm{L})$ interactions in various spiked dilutions of human plasma from 0.078 to $2.5 \%$ (volume of $100 \mu \mathrm{L}$ ) for non-specific interference response tests. In terms of the binding interaction characteristics of the carboxyl-GO-based SPR chip, the SPR angle shifts for human plasma concentrations of $0.078,0.156$, $0.313,0.625,1.25$ and $2.5 \%$ were $4.48,14.27,29.13,45.09$,
67.15 and $103.27 \mathrm{~m}^{\circ}$, respectively. These results showed that spiking human plasma in the tested sample clearly revealed severe non-specific interference and caused errors in the SPR angle shift. In order to reduce this interference of human plasma, we added BSA $(200 \mu \mathrm{g} / \mathrm{mL})$ and Tween-20 $(0.05 \%)$ in the test samples, which was effective in improving non-specific reactions and disrupting hydrophobic interactions between other protein analytes and sensor surfaces. ${ }^{43}$

Figure 7B shows the spiked human plasma experiments. The SHPRB consisted of $20 \%$ plasma, $0.05 \%$ Tween- 20 and $200 \mu \mathrm{g} / \mathrm{mL}$ BSA mixed in $60 \mathrm{~mL}$ of PBS. We used a series of diluted concentrations of PAPPA2 (0.01-10 ng/ $\mathrm{mL}$ ) which were diluted by the running buffer at a ratio of 1:1. The carboxyl-GO-based SPR chip was regenerated by washing with $50 \mathrm{mM} \mathrm{NaOH}(200 \mu \mathrm{L}$ each at $60 \mu \mathrm{L} / \mathrm{min})$. The SPR sensorgrams of the immunoassay interactions at an SPR angle equilibrium time of $300 \mathrm{~s}$ were obtained at $0.01 \mathrm{pg} / \mathrm{mL}, 0.1 \mathrm{pg} / \mathrm{mL}, 1 \mathrm{pg} / \mathrm{mL}, 10 \mathrm{pg} / \mathrm{mL}, 100 \mathrm{pg} / \mathrm{mL}$, $1 \mathrm{ng} / \mathrm{mL}$ and $10 \mathrm{ng} / \mathrm{mL}$ of PAPPA2 concentrations on the chip at $1.26,3.83,5.45,10.78,21.41,30.56$ and $37.29 \mathrm{~m}^{\circ}$, respectively.

The accuracy and precision of the carboxyl-GO-based SPR chip were checked according to the SPR angle response to different concentrations of PAPPA2. The calibration curves obtained for spiked human plasma for each linear range with error bars representing three replicates are shown in Figure 7C. The calibration curves were comprised of two sections with different slopes according to a low $(0.01-1 \mathrm{pg} / \mathrm{mL})$ and high $(1 \mathrm{pg} / \mathrm{mL}-10 \mathrm{ng} / \mathrm{mL})$ concentration range. The intersection of both curves was calculated and used as the cross point $(1 \mathrm{pg} / \mathrm{mL})$ for the domain of calibration. The results showed two ranges in which the calibration curve had good linearity. The first linear range with a low concentration had a regression equation of $y=2.25 x+5.78$ and a correlation coefficient $\left(R^{2}\right)$ of 0.989 , while the second linear range with a high concentration had a regression equation of $y=8.34 x+4.42$ and $R^{2}$ of 0.991 , where $y$ represents the SPR angle $\left(\mathrm{m}^{\circ}\right)$, and $\mathrm{x}$ is the PAPPA2 protein concentration. The error bars represent three replicate measurements. The experimental results showed that the carboxyl-GO-based SPR chip could detect protein in spiked plasma with more than $90 \%$ accuracy compared to the results obtained in PBS buffer.

Figure 7D shows the SPR kinetic analysis of the binding proteins over the carboxyl-GO-based SPR chip. The molecular interference in the high specificity antibodyantigen interactions revealed kinetic fitted values corresponding to $\mathrm{k}_{\mathrm{a}}$ and $\mathrm{K}_{\mathrm{D}}$ ranging from $1.6 \times 10^{5}$ to 

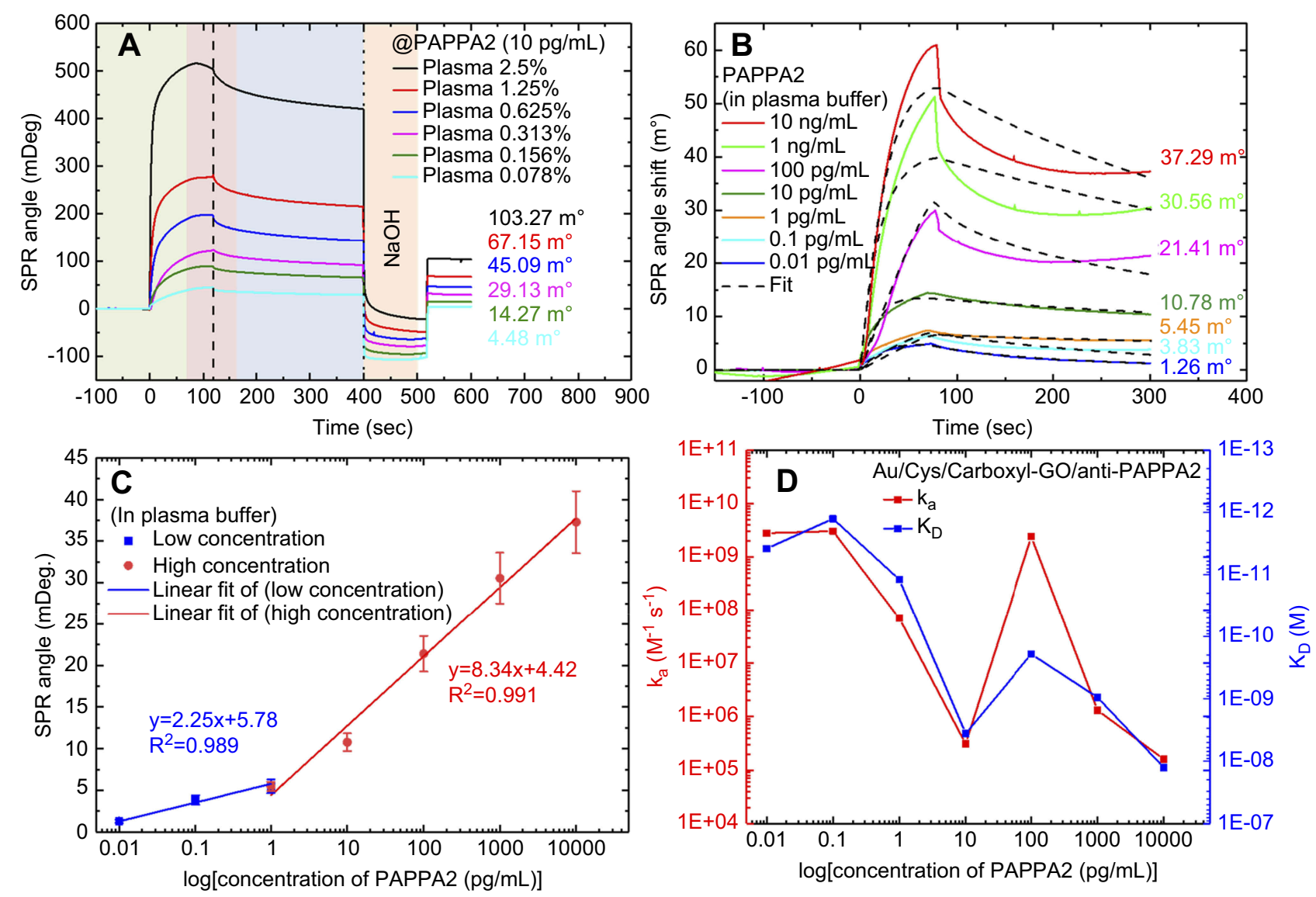

Figure 7 The SPR response curves of the carboxyl-GO-based SPR chip detection immunoassay during PAPPA2 and anti-PAPPA2 binding reactions in spiked human plasma. (A) The SPR sensorgrams of non-specific interference in different dilutions of human plasma. (B) Comparison of the efficiency of different concentrations of anti-PAPPA2 with PAPPA2 interactions. (C) Calibration curve of the average SPR response to various PAPPA2 protein concentrations. (D) Molecular binding affinity and kinetic analysis of the interaction factors.

Abbreviations: SPR, surface plasmon resonance; PAPPA2, pregnancy-associated plasma protein A2; Carboxyl-GO, carboxyl-graphene oxide; $\mathrm{K}_{\mathrm{D}}$, dissociation constant; $\mathrm{k}_{\mathrm{a}}$, association rate.

$3.1 \times 10^{9} \mathrm{M}^{-1} \mathrm{~S}^{-1}$ and $1.27 \times 10^{-8}$ to $3.8 \times 10^{-12} \mathrm{M}$ for the carboxyl-GO-based SPR chip in spiked human plasma, respectively. These results showed that the addition of BSA and Tween-20 effectively reduced the non-specific

Table 2 Affinity and assay for kinetic interactions of PAPPA2 proteins in spiked human plasma

\begin{tabular}{|l|l|l|l|}
\hline $\begin{array}{l}\text { PAPPA2 } \\
(\mathbf{p g} / \mathbf{m L})\end{array}$ & SPR angle $\left(\mathbf{m}^{\circ}\right)$ & $\mathbf{k}_{\mathbf{a}}\left(\mathbf{M}^{-1} \mathbf{S}^{-1}\right)$ & $\mathbf{K}_{\mathbf{D}}(\mathbf{M})$ \\
\hline 0.01 & 1.26 & $2.8 \times 10^{9}$ & $32.8 \times 10^{-12}$ \\
0.1 & 3.83 & $3.05 \times 10^{9}$ & $1.26 \times 10^{-12}$ \\
1 & 5.45 & $7.04 \times 10^{7}$ & $1.18 \times 10^{-11}$ \\
10 & 10.78 & $0.31 \times 10^{6}$ & $3.6 \times 10^{-9}$ \\
100 & 21.41 & $2.4 \times 10^{9}$ & $1.91 \times 10^{-10}$ \\
1000 & 30.56 & $1.32 \times 10^{6}$ & $9.52 \times 10^{-10}$ \\
10,000 & 37.29 & $0.16 \times 10^{6}$ & $1.27 \times 10^{-8}$ \\
\hline
\end{tabular}

Abbreviation: PAPPA2, pregnancy-associated plasma protein $A 2 ; K_{D}$, dissociation constant; $k_{a}$, association rate. effects of plasma and other interfering proteins and complex substances. Table 2 shows the assay and calculated affinity for kinetic interactions of PAPPA2 proteins in spiked human plasma.

\section{Conclusion}

In this study, we demonstrated that a carboxyl-GO composite can provide high affinity and be used as a label-free immunoassay without amplification steps to enhance SPR sensitivity. The experimental results showed that the carboxyl-GO composite could also be used to modulate and enhance the work function, conductivity properties and plasmon electric field for liquid interfaces. The results showed that this biosensor could detect a PAPPA2 concentration with an LOD as low as $0.01 \mathrm{pg} / \mathrm{mL}$ in PBS buffer and mixed interference proteins. The high specificity, selectively and affinity were excellent for the use as a carboxyl-GO-based SPR biosensor. The chip could be used to quantitatively analyze the PAPPA2 protein 
concentration in spiked human plasma with an LOD of $0.01 \mathrm{pg} / \mathrm{mL}$. Carboxyl-GO-based SPR biosensor technology, which is regarded to be critical in real-time point-of-care diagnostics (POCD) for newborn diseases, will be needed in countries with low fertility and an aging population. This study presents a very specific and potential development of a sensor which could be used in the future for whole blood diagnosis.

\section{Ethic statement}

This work was approved by the Institutional Review Board (IRB) of Mackay Hospital for Human Clinical Trials (Permit Number: 15MMHIS020 and 15MMHIS115).

\section{Acknowledgment}

The authors would like to thank the Ministry of Science and Technology of the Republic of China, Taiwan, for financially supporting this research under Contract No. MOST 106-2221-E-003-020, MOST 107-2221-E-003009, MOST 108-2221-E-003-020-MY3 and also Mackay Hospital (Project No. MMH-CT-10505). We thank Dr. Yao-Jane Hsu, Dr. Yao-Chang Lee, and Dr. Yaw-Wen Yang's groups for their help in analyzing XPS spectra (National Synchrotron Radiation Research Center, Beamline 09A2, 24A1 and 14A1).

\section{Disclosure}

The authors report no conflicts of interest in this work.

\section{References}

1. United Nations, Department of Economic and Social Affairs, Population Division (2017). World population ageing, 2018 (ST/ ESA/SER.A/408).

2. Available from: https://www.cia.gov/library/publications/the-worldfactbook/fields/356rank.html. Accessed August 02, 2019

3. Crosley EJ, Durland U, Seethram K, et al. First-trimester levels of pregnancy-associated plasma protein A2 (PAPP-A2) in the maternal circulation are elevated in pregnancies that subsequently develop preeclampsia. Reprod Sci. 2014;21:754-760. doi:10.1177/1933719113 512532

4. Nishizawa H, Pryor-Koishi K, Suzuki M, et al. Increased levels of pregnancy-associated plasma protein-A2 in the serum of pre-eclamptic patients. Mol Hum Reprod. 2008;14:595-602. doi:10.1093/molehr/ gan054

5. Munnangi S, Gross SJ, Mudankamar R, et al. Pregnancy associated plasma protein-A2: a novel biomarker for down syndrome. Placenta. 2014;35:900-906. doi:10.1016/j.placenta.2014.05.004

6. Buimer M, Keijser R, Jebbink JM, et al. Seven placental transcripts characterize HELLP-syndrome. Placenta. 2008;29:444-453. doi:10.1016/j.placenta.2008.02.007

7. Wagner PK, Otomo A, Christians JK. Regulation of pregnancy-associated plasma protein A2 (PAPPA2) in a human placental trophoblast cell line (BeWo). Reprod Biol Endocrinol. 2011;9:48-54. doi:10.1186/ 1477-7827-9-48
8. Page NM, Butlin DJ, Lomthaisong K, et al. The characterization of pregnancy associated plasma protein-E and the identification of an alternative splice variant. Placenta. 2001;22:681-687. doi:10.1053/ plac.2001.0709

9. Kloverpris S, Gaidamauskas E, Rasmussen LCV, et al. A robust immunoassay for pregnancyassociated plasma protein-A2 based on analysis of circulating antigen: establishment of normal ranges in pregnancy. Mol Hum Reprod. 2013;19:756-763. doi:10.1093/ molehr/gat047

10. Rodrigo D, Limaj O, Janner D, et al. Mid-infrared plasmonic biosensing with graphene. Science. 2015;349:165-168. doi:10.1126/science. aab2051

11. Singh M, Holzinger M, Tabrizian M, et al. Noncovalently functionalized monolayer graphene for sensitivity enhancement of surface plasmon resonance immunosensors. $J$ Am Chem Soc. 2015;137:2800-2803. doi:10.1021/ja511512m

12. Afkhami A, Hashemi $\mathrm{P}$, Bagheri $\mathrm{H}$, et al. Impedimetric immunosensor for the label-free and direct detection of botulinum neurotoxin serotype A using $\mathrm{Au}$ nanoparticles/graphene-chitosan composite. Biosens Bioelectron. 2017;93:124-131. doi:10.1016/j.bios.2016.09.059

13. Subramanian P, Barka-Bouaifel F, Bouckaert J, et al. Graphenecoated surface plasmon resonance interfaces for studying the interactions between bacteria and surfaces. ACS Appl Mater Interfaces. 2014;6:5422-5431. doi:10.1021/am405541z

14. Chiu NF, Yang CD, Chen CC, et al. Stepwise control of reduction of graphene oxide and quantitative real-time evaluation of residual oxygen content using EC-SPR for a label-free electrochemical immunosensor. Sens Actuators B Chem. 2018;258:981-990. doi:10.1016/j. snb.2017.11.187

15. Zhang H, Sun Y, Gao S, et al. A novel graphene oxide based surface plasmon resonance biosensor for immunoassay. Small. 2013;9:2537. doi: $10.1002 / \mathrm{smll} .201202958$

16. Chiu NF, Huang TY. Sensitivity and kinetic analysis of graphene oxide-based surface plasmon resonance biosensors. Sens Actuators B Chem. 2014;197:35-42. doi:10.1016/j.snb.2014.02.033

17. Chiu NF, Kuo CT, Lin TL, et al. Ultra-high sensitivity of the nonimmunological affinity of graphene oxide-peptide-based surface plasmon resonance biosensors to detect human chorionic gonadotropin. Biosens Bioelectron. 2017;94:351-357. doi:10.1016/j.bios.2017.03.008

18. Chiu NF, Chen CC, Yang CD, et al. Enhanced plasmonic biosensors of hybrid gold nanoparticle-graphene oxide-based label-free immunoassay. Nanoscale Res Lett. 2018;13:152-162. doi:10.1186/s11671018-2565-7

19. Stebunov YV, Aftenieva OA, Arsenin AV, et al. Highly sensitive and selective sensor chips with graphene-oxide linking layer. ACS Appl Mater Interfaces. 2015;7:21727-21734. doi:10.1021/acsami.5b04427

20. Peng S, Liu C, Fan X. Surface modification of graphene oxide by carboxyl-group: preparation, characterization, and application for proteins immobilization. Integr Ferroelectr. 2015;163:42-53. doi:10.1080/10584587.2015.1040328

21. Yang L, Li X, Yan S, et al. Single-walled carbon nanotubes-carboxyl-functionalized graphene oxide-based electrochemical DNA biosensor for thermolabile hemolysin gene detection. Anal Methods. 2015;7:5303-5310. doi:10.1039/C5AY01062D

22. Chiu NF, Fan SY, Yang CD, et al. Carboxyl-functionalized graphene oxide composites as SPR biosensors with enhanced sensitivity for immunoaffinity detection. Biosens Bioelectron. 2017;89:370-376. doi:10.1016/j.bios.2016.06.073

23. Sun X, Liu Z, Welsher K, et al. Nano-graphene oxide for cellular imaging and drug delivery. Nano Res. 2008;1:203-212. doi:10.1007/ s12274-008-8021-8

24. Becheru DF, Vlăsceanu GM, Banciu A, et al. Optical graphene-based biosensor for nucleic acid detection; influence of graphene functionalization and ionic strength. Int $J$ Mol Sci. 2018;19:3230. doi:10.3390/ijms 19103230 
25. Bocková M, Song XC, Gedeonová E, et al. Surface plasmon resonance biosensor for detection of pregnancy associated plasma protein A2 in clinical samples. Anal Bioanal Chem. 2016;408:7265-7269. doi:10.1007/s00216-016-9664-Z

26. Ni J, Pignatello JJ, Xing B. Adsorption of aromatic carboxylate ions to black carbon (Biochar) is accompanied by proton exchange with water. Environ Sci Technol. 2011;45:9240-9248. doi:10.1021/ es $201859 \mathrm{j}$

27. Megias-Alguacil D, Tervoort E, Cattin C, et al. Contact angle and adsorption behavior of carboxylic acids on $\alpha-\mathrm{Al} 2 \mathrm{O} 3$ surfaces. J Colloid Interface Sci. 2011;353:512-518. doi:10.1016/j.jcis.2010.09.087

28. Ritzefeld M, Sewald N. Real-time analysis of specific protein-DNA interactions with surface plasmon resonance. $J$ Amino Acids. 2012;2012:816032.

29. Chiu N-F, Lin T-L, Kuo C-T. Highly sensitive carboxyl-graphene oxide-based surface plasmon resonance immunosensor for the detection of lung cancer for cytokeratin 19 biomarker in human plasma. Sens Actuators B Chem. 2018;265:264-272. doi:10.1016/j. snb.2018.03.070

30. Verma S, Dutta RK. A facile method of synthesizing ammonia modified graphene oxide for efficient removal of uranyl ions from aqueous medium. RSC Adv. 2015;5:77192-77203. doi:10.1039/ C4RA14244F

31. Du Z, Dou R, Zu M, et al. Nitric oxide-generating L-cysteine-grafted graphene film as a blood-contacting biomaterial. Biomater Sci. 2016;4:938-942. doi:10.1039/C6BM00074F

32. Hadi A, Zahirifar J, Karimi-Sabet J, et al. Graphene nanosheets preparation using magnetic nanoparticle assisted liquid phase exfoliation of graphite: the coupled effect of ultrasound and wedging nanoparticles. Ultrason Sonochem. 2018;44:204-214. doi:10.1016/j. ultsonch.2018.02.028

33. Wang X, Sun Q, Cui C, et al. Anti-HER2 functionalized graphene oxide as survivin-siRNA delivery carrier inhibits breast carcinoma growth in vitro and in vivo. Drug Des Devel Ther. 2018;12:28412855. doi:10.2147/DDDT.S169430
34. Chiu NF, Tu YC, Huang TY. Enhanced sensitivity of anti-symmetrically structured surface plasmon resonance sensors with zinc oxide intermediate layers. Sensors. 2014;14:170-187. doi:10.3390/ s140100170

35. Rossi C, Homand J, Bauche C, et al. Differential mechanisms for calcium-dependent protein/membrane association as evidenced from SPR-binding studies on supported biomimetic membranes. $J$ Biochem. 2003;42:15273-15283. doi:10.1021/bi035336a

36. Zhang F, Wang Z, Wang D, et al. Optical limiting of carboxylgraphene oxide. IEEE J Sel Top Quant Electron. 2017;23:9000106. doi:10.1109/JSTQE.2016.2543140

37. Zhao X, Ma K, Jiao T, et al. Fabrication of hierarchical layer-by-layer assembled diamond-based core-shell nanocomposites as highly efficient dye absorbents for wastewater treatment. Sci Rep. 2017;7:44076. doi:10.1038/srep44076

38. Tu Q, Tian C, Ma T, et al. Click synthesis of quaternized poly(dimethylaminoethyl methacrylate) functionalized graphene oxide with improved antibacterial and antifouling ability. Colloids Surf B Biointerfaces. 2016;141:196-205. doi:10.1016/j.colsurfb.2016.01.046

39. Wirde M, Gelius U, Nyholm L. Self-assembled monolayers of cystamine and cysteamine on gold studied by XPS and voltammetry. Langmuir. 1999;15:6370-6378. doi:10.1021/la9903245

40. Hubert $\mathrm{J}$, Poleunis $\mathrm{C}$, Delcorte A, et al. Plasma polymerization of $\mathrm{C}_{4} \mathrm{Cl}_{6}$ and $\mathrm{C}_{2} \mathrm{H}_{2} \mathrm{Cl}_{4}$ at atmospheric pressure. Polymer. 2013;54:4085e4092. doi:10.1016/j.polymer.2013.05.068

41. Abdulrazzaq O, Bourdo SE, Saini V, et al. Tuning the work function of polyaniline via camphorsulfonic acid: an X-ray photoelectron spectroscopy investigation. RSC $A d v$. 2015;5:33-40. doi:10.1039/ C4RA11832D

42. Chiu NF, Huang TY, Lai HC, et al. Graphene oxide-based SPR biosensor chip for immunoassay applications. Nanoscale Res Lett. 2014;9:445-451. doi:10.1186/1556-276X-9-445

43. Drescher DG, Ramakrishnan NA, Drescher MJ. Surface plasmon resonance (SPR) analysis of binding interactions of proteins in inner-ear sensory epithelia. Methods Mol Biol. 2009;493:323-343. doi:10.1007/978-1-59745-523-7 14
International Journal of Nanomedicine

\section{Publish your work in this journal}

The International Journal of Nanomedicine is an international, peerreviewed journal focusing on the application of nanotechnology in diagnostics, therapeutics, and drug delivery systems throughout the biomedical field. This journal is indexed on PubMed Central, MedLine, CAS, SciSearch ${ }^{\mathbb{}}$, Current Contents ${ }^{\mathbb{R}} /$ Clinical Medicine,

\section{Dovepress}

Journal Citation Reports/Science Edition, EMBase, Scopus and the Elsevier Bibliographic databases. The manuscript management system is completely online and includes a very quick and fair peer-review system, which is all easy to use. Visit http://www.dovepress.com/ testimonials.php to read real quotes from published authors. 